\title{
Fraud Governance Case
}

\author{
by Fred van \\ Eenennaam \\ (the Netherlands)
}

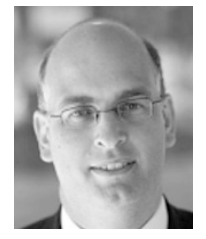

and Hagar Michel (Switzerland/ the Netherlands)

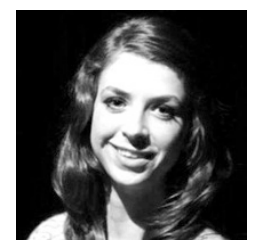

\section{VBHC, Center Europe International Center for Corporate Governance The Decision Institute}

Gerard van de Aast was appointed as board member of the 150-year-old technical services provider Royal Imtech N.V. (Imtech) in December 2012. Imtech was the darling of the Dutch stock exchange AEX with an order book of 27,000 projects, 29,000 employees and revenue of approximately 5.5 billion euros. By April 2013, Van de Aast would replace Imtech's CEO Van der Bruggen who had led the company since 2002 together with CFO Gerner.

Imtech's targets for 2015 were revenue of 8 billion euros and an operational EBITA margin between 6 and 7\%. Between 2001 and 2013, Imtech acquired an aggregate of 86 companies in the Benelux, Germany, Austria, Eastern Europe, the UK, Scandinavia, Turkey and Spain. Imtech Germany and Eastern Europe (Imtech Germany) was the most profitable subsidiary of Imtech. In 2010, Imtech Germany had an EBITA margin of 8.3\%, a revenue growth of $18 \%$ to 1.3 billion and an order book growth of $14 \%$.

Imtech's working capital position had been a point of conversation since August 2011 and reached a new actual record by March 2012: approximately 47\% of trade receivables were overdue, of which $22 \%$ more than 2 months. From that moment onward, the audit committee, analysts and investors repeatedly expressed concerns about the working capital position of Imtech, the rapid growth of the order book and revenue (particularly in Germany) and the upcoming departure of the CEO and CFO of Imtech.

A 155 million euros mechanical and electrical contract for a Polish amusement park called Adventure World Warsaw (AWW) was approved of by Imtech Germany in July 2011. The contract grew to 680 million euros but subsequently failed to secure financing. In March 2012, Imtech had to provide guarantees for a quarter of the contract price of the project (147.6 million euros incl. taxes). Imtech Germany's CEO suggested to make an advance payment through a promissory note, an agreement between AWW and Imtech Poland that stated AWW would pay the guarantees. 
Over the course of 2012, the promissory note expired twice without financing. In November an analyst from ABN Amro advised to sell shares, and, in the same month, Imtech's accountant KPMG stated that the promissory note could not be included in the 2012 annual results as cash and cash equivalents. A second opinion from EY, requested by the board of management, stated the same in January 2013.

On the morning of February 27, 2013, Van de Aast received an overview of incurred costs on Imtech's biggest project in history: 70 million euros had been spent on the 680 million euros AWW project. The highest amounts listed were payments to companies that did not exist according to Google, and all management involved in the project was not able to provide satisfactory answers on questions posed.

After a supervisory board meeting and an initial dive into the AWW issue, Van de Aast asked Rabobank for 200 million euros extra borrowing capacity and instructed Imtech Germany's CEO to suspend the CEO and CFO of Imtech Poland together with 31 key employees. Imtech announced a write-off of at least 100 million euros on the Polish project, a forensic investigation into possible irregularities and the postponement of the publication of the 2012 results. Imtech Germany's CEO and CFO were dismissed the day after.

A new CFO and two others were added to the board of management of Imtech. Two of the six supervisory board members stayed and two new members joined, while three other potential supervisory board members would join when future funding was set. KPMG stayed on as accountant to deliver the annual report, and a 500 million euros rights issue underwritten by ING and Rabobank was announced to strengthen Imtech's equity, used for debt reduction.

Van de Aast prepared to meet with the chairman of the supervisory board to discuss further steps. What should he propose as his first steps? And what should be the role of the rest of the board of management, the supervisory board members, auditors and banks?

\section{$1 \quad$ What Happened in Reality?}

- The focus of the new board of management was threefold: mapping past events and making them public, operational excellence (with a strong focus on ethics, control and decentralized management models) and financial recovery. Dozens of advisors were hired to help in the process.

- Newspapers continuously published articles about possible price fixing and fraud, and Imtech stated time and again that they were looking into all past events.

- Imtech's operational result was disappointing, and the financial performance was lower than expected. It became clear that Imtech had historically inflated its performance using accounting schemes, which was reflected in its working capital. Customers left, cash flow and revenue declined by 2013, and by 2014, driven by the de-risking behaviour of its financiers, the implied interest rose from around $5 \%$ to $16.4 \%$. As a result of the increased interest charges, Imtech no longer generated cash and was unable to repay its outstanding debt from operating cash flows. The outstanding bank guarantees amounted to 897 million euros with headroom under existing guarantee facilities of 155 million. 
- Imtech had sold its ICT and Turkish businesses, and a second rights issue of 600 million euros was announced which diluted the existing equity to less than $0.8 \%$ of total equity. $52.44 \%$ of the rights were exercised in the second rights issue, and ING bank, Rabobank, COMMERZBANK and ABN Amro bank became holders of the remainder of Imtech's outstanding and issued share capital.

- Imtech Germany filed for bankruptcy in August 2015, and the appointed administrators sold most assets of Imtech throughout 2015 and 2016.

- Two administrative fines of, respectively, 1 and 1.25 million euros to the former CEO Van der Bruggen and CFO Gerner of Imtech were dismissed: there was no law that forced the Imtech directors to disclose information on Imtech's finances, as long as the directors did not doubt financing would come through.

- In February 2017 the former CEO of Imtech Germany was sentenced to almost 4 years in jail for making 47 illegal payments of almost 3 million euros to a firm that was owned by the man who was Imtech Germany's CEO until 2002.

\section{What Are the Most Important Lessons Learned from This Case for the Effective Direction and Control of Companies?}

- An aggressive growth strategy is not sustainable: the targets for 2015 would mean Imtech expected that the historic average revenue growth of $14 \%$ could be persisted until 2015-during crisis times.

- 'If it's too good to be true, it's probably not true': business controls are important with decentralized units. Only trust is not enough in an organization the size of Imtech, an eye has to be kept on working capital position, outstanding guarantees and gross debt of the entire organization to see if unwanted practices are taking place.

- Sanity checks are always necessary: Is building an amusement park in the midst of a crisis wise? And after the fraud was discovered, was a 500 million right issue enough to go through the whole change process, including the financial consequences that a fraudulent department brought along?

Open Access This chapter is licensed under the terms of the Creative Commons Attribution 4.0 International License (http://creativecommons.org/licenses/by/4.0/), which permits use, sharing, adaptation, distribution and reproduction in any medium or format, as long as you give appropriate credit to the original author(s) and the source, provide a link to the Creative Commons licence and indicate if changes were made.

The images or other third party material in this chapter are included in the chapter's Creative Commons licence, unless indicated otherwise in a credit line to the material. If material is not included in the chapter's Creative Commons licence and your intended use is not permitted by statutory regulation or exceeds the permitted use, you will need to obtain permission directly from the copyright holder. 